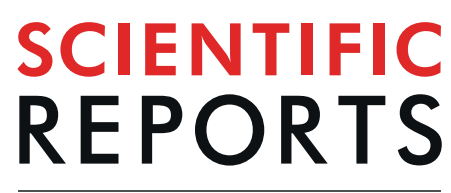

natureresearch

\title{
OPEN An assessment of oil palm plantation aboveground biomass stocks on tropical peat using destructive and non-destructive methods
}

\author{
Kennedy Lewis ${ }^{1 *}$, Elisa Rumpang ${ }^{2}$, Lip Khoon $\mathrm{Kho}^{2}$, Jon McCalmont ${ }^{1}$, Yit Arn Teh ${ }^{3}$, \\ Angela Gallego-Sala ${ }^{1}$ \& Timothy Charles Hill ${ }^{1}$
}

The recent expansion of oil palm (OP, Elaeis guineensis) plantations into tropical forest peatlands has resulted in ecosystem carbon emissions. However, estimates of net carbon flux from biomass changes require accurate estimates of the above ground biomass (AGB) accumulation rate of $O P$ on peat. We quantify the AGB stocks of an OP plantation on drained peat in Malaysia from 3 to 12 years after planting using destructive harvests supported by non-destructive surveys of a further 902 palms. Peat specific allometric equations for palm $\left(R^{2}=0.92\right)$ and frond biomass are developed and contrasted to existing allometries for OP on mineral soils. Allometries are used to upscale AGB estimates to the plantation block-level. Aboveground biomass stocks on peat accumulated at $\sim 6.39 \pm 1.12 \mathrm{Mg} \mathrm{ha}^{-1}$ per year in the first 12 years after planting, increasing to $\sim 7.99 \pm 0.95 \mathrm{Mg} \mathrm{ha}^{-1} \mathrm{yr}^{-1}$ when a 'perfect' plantation was modelled. High inter-palm and inter-block AGB variability was observed in mature classes as a result of variations in palm leaning and mortality. Validation of the allometries defined and expansion of non-destructive inventories across alternative plantations and age classes on peat would further strengthen our understanding of peat OP AGB accumulation rates.

Global demand for palm oil has risen such that the land area supporting oil palm (OP, Elaeis guineensis) planta-

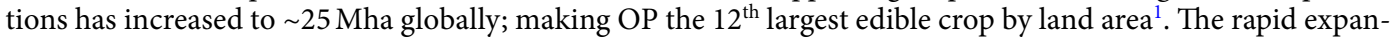
sion of OP in Insular Southeast Asia during the last quarter decade has resulted in the conversion of 3.1 Mha of tropical peatlands ${ }^{2}$. The carbon emissions from the oxidation of soil organic matter following the conversion of peat swamp forest to OP are relatively well known, yet the net carbon emission of peat swamp forest conversion to OP across the life of a plantation remains poorly constrained ${ }^{3-6}$. In part, uncertainty is attributed to a scarcity of literature which addresses the rate at which OP on peat accumulates carbon in biomass over time ${ }^{6-10}$. The majority of OP standing biomass is stored as aboveground biomass (AGB) constituting $84 \%$ of biomass stocks, with the reminder (16\%) stored as belowground biomass (BGB); consequently, efforts here focus primarily on AGB quantification ${ }^{11-13}$.

Recent efforts to quantify the AGB stocks of forests and plantations have increasingly used remote sensing techniques ${ }^{14,15}$. However, remote sensing estimates ultimately rely on direct ground-based measurement of AGB stocks either for calibration or validation ${ }^{15,16}$. Forest and plantation vegetation is destructively harvested to obtain the vegetation dry-weight (DW) and infer biomass carbon stocks ( 47.4\% of dry biomass $)^{17,18}$. These destructive measurements are essential but are costly in terms both of time and resources; allometric equations which relate AGB stocks to non-destructive or semi-destructive measurements of vegetation structural characteristics are therefore invaluable ${ }^{18,19}$. Destructive and non-destructive AGB stock estimates are common for OP on mineral soils but are almost entirely absent for OP on peat ${ }^{6,8,10,20}$. Furthermore, much of the literature and allometries are

${ }^{1}$ Geography, College of Life and Environmental Sciences, University of Exeter, Streatham Campus, Rennes Drive, Exeter, EX4 4RJ, UK. ${ }^{2}$ Tropical Peat Research Institute, Biological Research Division, Malaysian Palm Oil Board, 6, Persiaran Institusi, Bandar Baru Bangi, 43000, Kajang, Selangor, Malaysia. ${ }^{3}$ School of Natural and Environmental Science, Newcastle University, Drummond Building, Newcastle-upon-Tyne, NE1 7RU, UK. *email: kI378@exeter.ac.uk 

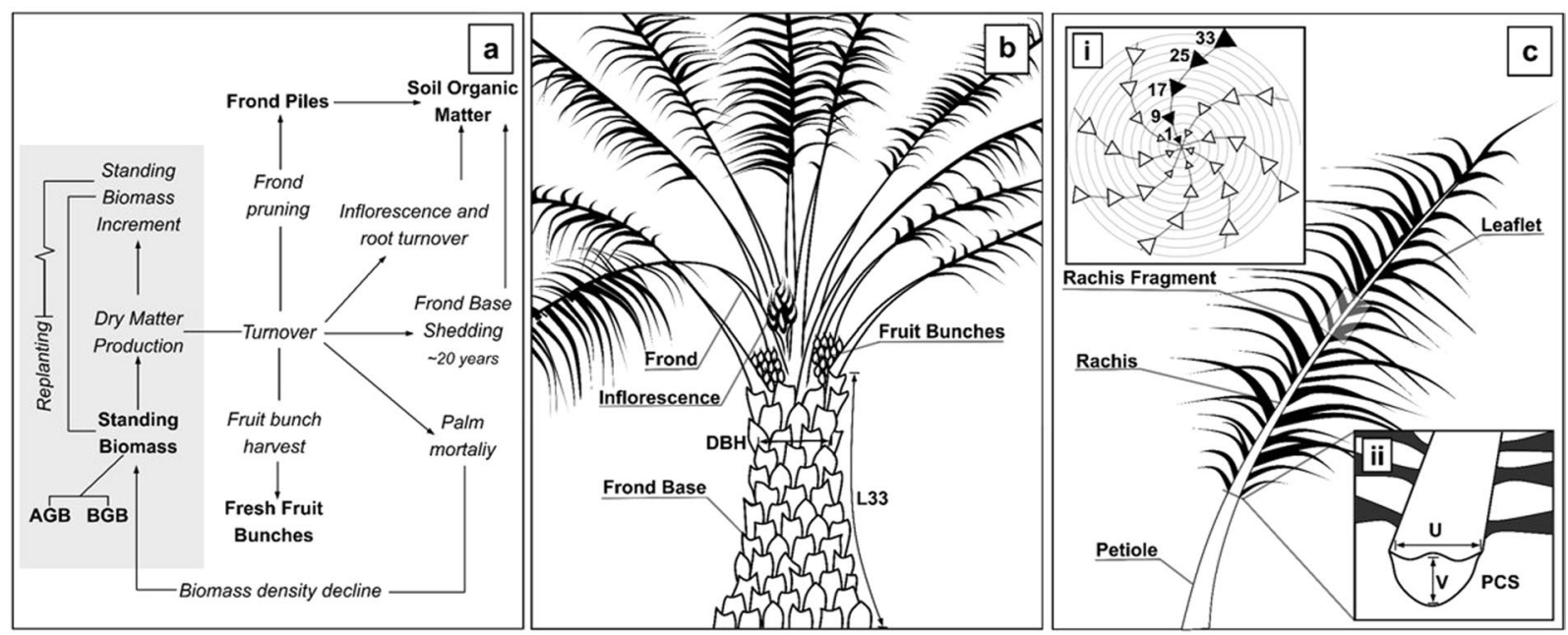

Figure 1. Oil palm AGB components, turnover and measurement. (a) Biomass turnover and stocks across a 25year planting cycle. (b) An upright Young Mature oil palm with DBH (measured at $1.3 \mathrm{~m}$ excluding frond bases) and trunk length to the frond ranked 33 (L33) indicated. (c) Labelled frond diagram, (ci) indicates frond rank numbering and crown phyllotaxis (after Aholoukpè et al., 2013), (cii) demonstrates PCS (petiole cross sectional area) measurement where $\mathrm{PCS}=\mathrm{U} \times \mathrm{V}$, a rachis fragment is taken from the rachis midpoint.

contained within 'grey' literature. The lack of published direct ground-based estimates of AGB for OP on peat is also a major limitation for remotely sensed estimates of OP AGB and in carbon bookkeeping models $s^{6,21,22}$.

OPs are typically managed for a planting cycle of $\sim 25$ years after which profitability reduces and the next cropping rotation is initiated ${ }^{23}$. However, during each growing cycle only a proportion of the biomass produced is retained by the palm to augment its existing biomass, the remainder is lost as a result of the natural and managed turnover of fruit, inflorescences, fronds and frond bases (Fig. 1a) ${ }^{10,23,24}$. Fruit bunches develop in the axil of each frond and are harvested cyclically. Fronds emerge at a rate of 20-25 fronds per year and are progressively pruned before being plied on the plantation floor during harvesting rounds ${ }^{23,25}$. Frond bases; which are left adhering to trunk subsequent to pruning accumulate during the early to middle years of the planting cycle and are typically shed $\sim 12$ years after planting ${ }^{23}$. The single growing apex of OPs, absence of secondary stem thickening once mature and regular phyllotaxis of fronds within the palm crown mean they are well suited to dry weight quantification and allometric development (Fig. 1b,c) ${ }^{26,27}$. On mineral soils allometric equations have been produced to monitor each palm AGB component in order to accurately equate biomass stocks and turnover spatially and over time (Table 1). However, many OP AGB assessments state biomass values without information pertaining to planting density and local environment and are subject to uncertainties associated with a lack of standardised methods (Supplementary Table S1) ${ }^{8,9}$. Models of OP biomass stock accumulation on mineral soils have also been developed and have been incorporated into large scale LUC carbon flux and bookkeeping models ${ }^{8,21,28-30}$.

OP plantations on peat are markedly different to those on mineral soils with potential impacts on AGB stock estimations. Following the clearance of forest biomass, peatlands are drained to an optimum water table depth $0.4-0.6 \mathrm{~m}$ from the peat surface to allow cultivation ${ }^{31-33}$. Peat bulk density is increased to $\sim 0.20 \mathrm{~g} \mathrm{~cm}^{-1}$ by mechanical compaction using heavy machinery, often including the compaction of residual forest material into the peat ${ }^{31,34,35}$. This increases the load-bearing capacity of peat soils and improves the anchorage of OPs which allocate a relatively small proportion of total biomass to belowground root systems ${ }^{11,32-34}$. Following this initial compaction further peat subsidence occurs as a result of peat shrinkage, consolidation and decomposition following drainage ${ }^{36}$. This subsidence, when combined with poor root anchorage, frequently results in individual palms leaning at an angle to the ground. As leaning becomes more severe roots become exposed and vulnerable to desiccation and breakage which can result in the palms falling over entirely, the likelihood of this increases as palms mature with associated gains in trunk and crown biomass ${ }^{32}$. This has become a serious limiting factor for OP performance on peat and will likely have detrimental effects on AGB stocks as plant density per area is reduced due to palm mortality (Fig. 1a) ${ }^{10,32,33}$. Initial palm planting densities ore optimised for maximum fresh fruit bunch (FFB) yield across the life of the plantation, higher densities are therefore adopted for less favourable soils ${ }^{24}$. In contrast to OP on mineral soils, optimal planting densities on peat range from 160 to 200 palms per hectare (110-148 palms per hectare on mineral soils $)^{10,24,33}$.

In this study, we quantify the AGB (dry-weight) of OPs on deep peat in Sarawak, Malaysia. Destructive harvests of nine palms split amongst three age classes (IM: immature, YM: young-mature and M: mature) are supported with non-destructive measurements and surveys of a further 902 palms. Harvest data is used to develop new allometric equations for palm and component AGB. Non-destructive measurements are then used to upscale the destructive harvests to the plantation block level. We develop models of AGB accumulation rates on peat to inform existing OP AGB growth and carbon balance models. Finally, a meta-analysis of existing OP allometries for palms on both peat and mineral soils is performed and the results contrasted with data and allometries developed as part of this study. 


\begin{tabular}{|c|c|c|c|c|}
\hline No & Component & Equation & Source & Note \\
\hline \multicolumn{5}{|c|}{ Allometries Tested } \\
\hline 1 & Frond DW & $D W_{\text {Frond }}=0.102 \times P C S+0.21$ & Corley et al., 1971 & - \\
\hline 2 & Frond DW & $\begin{array}{l}D W_{\text {Frond }}=\alpha+\beta \times P C S \\
\alpha=-0.0076+0.0394 \times Y A P \\
\beta=0.0284+0.0101 \times Y A P\end{array}$ & $\begin{array}{l}\text { Henson (1993): in } \\
\text { Hanson and Dolmat } \\
2003\end{array}$ & Palms YAP $\leq 6$ \\
\hline \multirow[t]{2}{*}{3} & Rachis DW & $D W_{\text {Rachis }}=1.133 \times \frac{D W_{\text {Frag }}}{L_{\text {Frag }}} \times L_{\text {Rachis }}$ & Aholoukpè et al., 2013 & - \\
\hline & Frond DW & $D W_{\text {Frond }}=1.147+2.135 \times D W_{\text {Rachis }}$ & & \\
\hline 4 & Trunk DW & $D W_{\text {Trunk }}=T_{\text {Vol }} \times \rho=\rho\left(\pi r^{2} \times L_{\text {Trunk }}\right)$ & Corley et al., 1971 & $\begin{array}{l}\text { Trunk biomass } \\
\text { without frond } \\
\text { bases }\end{array}$ \\
\hline & Trunk Density & $\rho=0.0076 \times Y A P+0.083$ & & \\
\hline \multicolumn{5}{|c|}{ Biomass Accumulation Models } \\
\hline M1 & $\begin{array}{l}\text { Standing Biomass } \\
\left(\mathrm{Mg} \mathrm{ha}^{-1}\right)\end{array}$ & $\begin{aligned} S B= & -0.00020823 \times Y A P^{4} \times 0.000153744 \times Y A P^{3} \\
& -0.011636 \times Y A P^{2}+7.3219 \times Y A P-6.3934\end{aligned}$ & Henson, 2003 & $\begin{array}{l}\text { Standing biomass, } \\
\text { adjusted to AGB } \\
\text { (Morel } \text { et al., } \\
\text { 2011). }\end{array}$ \\
\hline M2 & $\begin{array}{l}\text { Aboveground } \\
\text { Biomass }\left(\mathrm{Mg} \mathrm{ha}^{-1}\right)\end{array}$ & $A G B=18.95 \times Y A P^{0.5}$ & $\begin{array}{l}\text { Germer and Sauerborn, } \\
2006\end{array}$ & - \\
\hline M3 & $\begin{array}{l}\text { Aboveground } \\
\text { Biomass }\left(\mathrm{Mg} \mathrm{ha}^{-1}\right)\end{array}$ & $A G B=1.526\left(5.97 \times Y A P^{0.62}\right)$ & Carlson et al., 2012 & $\begin{array}{l}\text { Model adjusted to } \\
\text { carbon to AGB }\end{array}$ \\
\hline
\end{tabular}

Table 1. Existing allometric equations for the estimation of OP component dry weight (kg) and OP AGB accumulation models for OP on mineral soils. Where $\mathrm{DW}_{\text {Frond }}$ is frond dry weight $(\mathrm{kg})$, PCS is the petiole cross sectional area $(\mathrm{cm}), \mathrm{DW}_{\text {Rachis }}$ is rachis dry weight $(\mathrm{kg}), \mathrm{DW}_{\text {Frag }}$ is rachis fragment dry weight $(\mathrm{kg}), \mathrm{L}_{\text {Frag }}$ is rachis fragment length $(\mathrm{m}), \mathrm{L}_{\text {Rachis }}$ is rachis length $(\mathrm{m}), \mathrm{DW}_{\text {Trunk }}$ is trunk dry weight, $\mathrm{T}_{\text {Height }}$ is trunk height $(\mathrm{m}), \mathrm{DW}_{\text {Palm }}$ is palm dry weight $(\mathrm{kg}), \mathrm{T}_{\mathrm{Vol}}$ is trunk volume $\left(\mathrm{m}^{3}\right), \mathrm{DBH}$ is the diameter at breast height $(\mathrm{m})$ and YAP is years after planting.

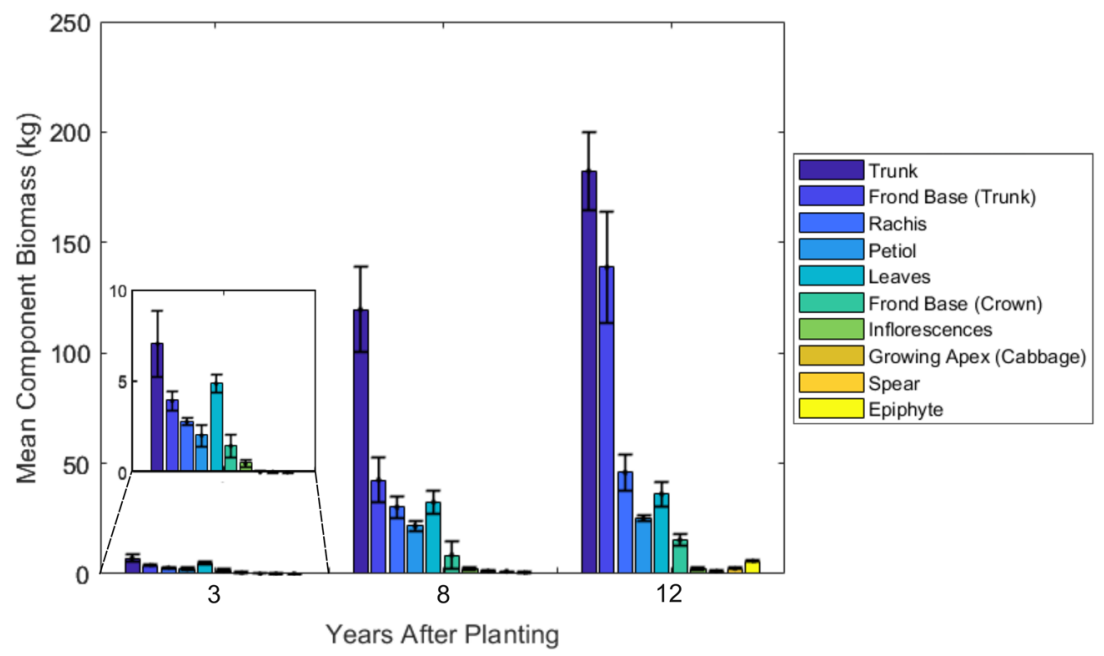

Figure 2. Mean AGB component dry weights $(\mathrm{kg})$ for immature, young mature and mature OPs. Error bars indicate standard error. Frond Base (Crown) is the remaining frond base left in the crown subsequent to live frond removal (see methods).

\section{Results}

OP biomass distribution in immature, young-mature and mature palms. Of the palms destructively harvested, one mature palm was mildly leaning (Supplementary Table S2). As expected, the palm trunk makes the largest contribution (33 to $46 \%$ ) to the total palm dry weight ( $\mathrm{DW}_{\text {palm }}$ ), particularly in the YM and $\mathrm{M}$ classes (Fig. 2). Frond base biomass also constitutes a large proportion of the overall biomass (13 to 32\%), again particularly in the older age classes (Fig. 2, Table 2). Palm trunks retained all frond bases in all palms harvested. In immature palms, fronds make up a larger proportion of overall biomass.

Contrasting palm trunk and total frond dry weight for each age class to those on mineral soils revealed no differences (Fig. 3). However, accessible data was scarce on both mineral and peat soils. 


\begin{tabular}{|c|c|c|c|c|c|c|c|c|c|c|}
\hline \multirow[b]{2}{*}{ YAP } & \multicolumn{3}{|l|}{ Stem } & \multicolumn{4}{|l|}{ Frond } & \multirow[b]{2}{*}{ Spear } & \multirow[b]{2}{*}{ Cabbage } & \multirow[b]{2}{*}{ Total (All) } \\
\hline & Trunk & Frond Base & Total & Rachis & Petiole & Leaflet & Total & & & \\
\hline 3 & \begin{tabular}{|l|l|}
$7.0 \pm 1.8$ \\
\end{tabular} & $3.9 \pm 0.5$ & 11.0 & $2.8 \pm 0.2$ & $2.0 \pm 0.9$ & $4.9 \pm 0.5$ & 9.7 & $0.3 \pm 0.1$ & \begin{tabular}{|l|}
$0.3 \pm 0.1$ \\
\end{tabular} & $21.3 \pm 5.9$ \\
\hline 8 & $111.8 \pm 19.3$ & $42.5 \pm 10.2$ & 154.3 & \begin{tabular}{|l|}
$30.2 \pm 4.9$ \\
\end{tabular} & $21.3 \pm 2.6$ & $32.3 \pm 5.1$ & 83.8 & $1.2 \pm 0.1$ & $1.3 \pm 0.6$ & $240.6 \pm 15.3$ \\
\hline 12 & $182.4 \pm 17.6$ & $138.8 \pm 25.2$ & 321.2 & $45.7 \pm 8.1$ & $25.0 \pm 1.4$ & \begin{tabular}{|l|}
$36.1 \pm 5.7$ \\
\end{tabular} & 106.9 & $2.4 \pm 0.4$ & $1.3 \pm 0.5$ & $431.8 \pm 90.1$ \\
\hline
\end{tabular}

Table 2. Mean AGB component dry weights (kg) for immature, young mature and mature OPs (standard error indicated).

Allometric estimation of palm and frond component biomass. Harvest data was used to validate existing allometric equations and develop equations for Malaysian OP on deep peat (Tables 1 and 3).

Frond DW estimation. Existing allometric equations estimating frond dry weight $\left(\mathrm{DW}_{\text {frond }}\right)$ using the petiole cross sectional area (PCS) (Equation (1) and (2)) and rachis linear density (RLD) (Equation (3)) were tested. The petiole cross sectional area is the sectional area at the junction of the petiole and rachis (at the point of insertion of the lowest leaflet) (Fig. 1c). The rachis linear density is derived from the dry weight of a rachis fragment and is used to predict rachis dry weight $\left(\mathrm{DW}_{\text {Rachis }}\right)$ and infer $\mathrm{DW}_{\text {Frond }}$.

All existing allometric equations tested overestimated frond dry weight (Supplementary Fig. S1). Frond DW estimation using the petiole cross sectional area (Equation (1)) overestimated $\mathrm{DW}_{\text {frond }}$ by $\sim 56 \%$ for young mature and mature palms and $\sim 119 \%$ for immature palms. However, using to Equation 2 to estimate $\mathrm{DW}_{\text {frond }}$ from the PCS for palms $<6$ years after planting improved estimation in the immature age class, overestimating frond dry weight by only $21 \%$. Estimation using rachis linear density (Equation (3)) resulted in an overestimation of $~ 61 \%$ for young mature and mature palms and $\sim 300 \%$ for immature palms. Rachis dry weight was however well predicted from rachis linear density (Equation (3), Supplementary Fig. S2). Further allometries referred to in Corley

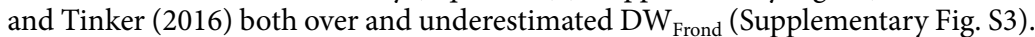

Allometric relationships for $\mathrm{DW}_{\text {frond }}$ estimation on deep peat were then defined. Frond dry weight in each age class was lower than reported for palms on mineral soils but was more consistent with those sampled by Henson and Dolmat (2003) from OPs on peat (Supplementary Fig. S4). Leaflets in immature palms made a larger contribution to overall frond dry weight when compared to the mature age classes (Supplementary Fig. S5), equations were adjusted to include all palm ages sampled. Rachis linear density was a marginally better predictor of $\mathrm{DW}_{\text {Frond }}$ $\left(R^{2}=0.83\right)$, when compared to the petiole cross section $\left(R^{2}=0.76\right)$ once adjusted to harvested fronds (Fig. 4). However, estimation of $\mathrm{DW}_{\text {Frond }}$ using the petiole cross sectional area was considered more practical in the field. Rachis length was also used to predict $\mathrm{DW}_{\text {Frond }}$ to a similar degree of accuracy $\left(\mathrm{R}^{2}=0.81\right)$.

Palm DW estimation. The palm trunk makes the greatest proportional contribution to overall palm biomass (Fig. 2). Equation (4) underestimated trunk dry weight by 32\% in YM and M palms (frond bases not included). Total palm DW ( $\mathrm{DW}_{\text {palm }}$ ) is estimated using trunk height (height to frond 33) in existing allometries (Supplementary Table S3). Whilst trunk length was found to be a good estimator of $\mathrm{DW}_{\text {palm }}\left(\mathrm{R}^{2}=0.88\right)$, the use of trunk volume was marginally more effective for the palms sampled $\left(\mathrm{R}^{2}=0.92\right)$ (Equation (8)) (Fig. 5). A model was developed to predict $\mathrm{DW}_{\text {palm }}$ excluding frond bases to simulate frond base shedding, however $\mathrm{R}^{2}=0.52$, potentially due to a small sample size $(n=6)$ and the highly variable contribution of frond bases to the overall $\mathrm{DW}_{\text {palm }}$ of palms sampled.

Upscaling biomass to the plantation block scale. Non-destructive measurements were combined with the allometric equations defined for $\mathrm{OP}$ on peat to assess biomass stocks at the plantation block level. Equation (8) was used to estimate the biomass stock of live palms in 220.25 ha plots in plantation blocks at various stages of maturity (Fig. 6). This confirmed a large variation in biomass stocks in the more mature plots with a mean AGB of $65.9 \pm 8.7 \mathrm{Mg} \mathrm{ha}^{-1} 11$ years after planting and $56.04 \pm 12.0 \mathrm{Mg} \mathrm{ha}^{-1}$ after 12 years (Fig. 6). When a 'perfect' plantation on peat is modelled, disregarding fallen, missing and re-planted palms (which represented $13 \%$ of palms in plots $>8$ YAP) aboveground biomass stocks accumulated at $\sim 7.99 \pm 0.95 \mathrm{Mg} \mathrm{ha}^{-1} \mathrm{yr}^{-1}$ in the first 12 years after planting. However, this is reduced to $\sim 6.39 \pm 1.12 \mathrm{Mg} \mathrm{ha}^{-1}$ per year considering all 22 assessed plantation blocks when palm mortality and replacement is taken into account. Mild and severely leaning palms made up $17 \%$ of live palms in plots $>8 \mathrm{YAP}$, however, inter-plot variation within age classes across the plantation was high.

Aboveground biomass stocks at the study site were compared to assessments of OP AGB on mineral soils in addition to comparison with AGB accumulation models (Fig. 6). Only 3 accessible assessments of OP AGB stocks on peat soils where available (Fig. 6). At the time of survey there were no planting blocks aged $>12$ YAP at the study site. Henson (2003), Model M1, assumes an AGB reduction $~ 18$ years after planting due to frond base shedding. In contrast, Models M2 and M3 do not indicate this reduction (Fig. 7). Peat OP AGB at the Sabaju and Sebungan Estates appears consistent with OP on mineral soils. However, in mature blocks where palm falling and missing palms were common AGB stocks were notably lower than modelled OP growth (Figs. 6 and 7).

\section{Discussion}

Dry weight distribution of OP on peat. The dry weight of OPs in three age classes was quantified using destructive harvests. As palms transitioned from youth to maturity trunk length and dry weight increased, this was also accompanied by an increase in frond base biomass relative to the total palm dry weight. Studies that destructively harvest frond bases to quantify biomass are few when compared with other AGB 

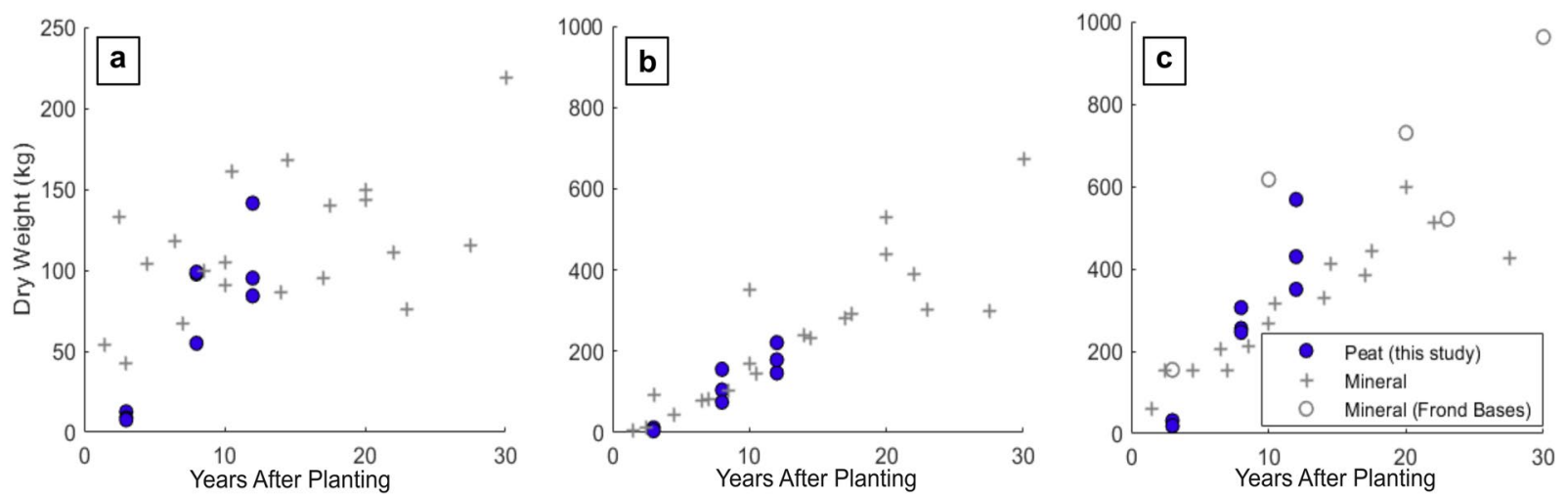

Figure 3. Dry weights of OP components (kg). Dry weights where quantified using destructive harvests including total frond biomass per palm (a), palm trunk biomass (b) and palm biomass (excluding fruit and epiphytes) (c). Per palm DWs of OP AGB components on mineral soils are taken from Corley et al. (1971), Khalid et al., (1999), Rees and Tinker (1963) and Syahrinudin (2005). Frond base biomass is included in palm (total) where reported ((c) - grey open circle).

\begin{tabular}{|c|c|c|c|}
\hline No & Component & Equation & Note \\
\hline \multicolumn{4}{|c|}{ Derived Allometries } \\
\hline 5 & Frond DW & $D W_{\text {Frond }}=0.060 \times P C S+0.217$ & $\begin{array}{l}\text { Frond DW estimation using the petiole cross sectional } \\
\text { area of a pruned frond. }\end{array}$ \\
\hline \multirow[t]{2}{*}{6} & Rachis DW & $D W_{\text {Rachis }}=1.126 \times \frac{D W_{\text {Frag }}}{L_{\text {Frag }}} \times L_{\text {Rachis }}$ & $\begin{array}{l}\text { Frond DW estimation using the DW of a rachis } \\
\text { fragment taken from a pruned frond. }\end{array}$ \\
\hline & Frond DW & $D W_{\text {Frond }}=0.176+2.267 \times D W_{\text {Rachis }}$ & \\
\hline 7 & Frond DW & $D W_{\text {Frond }}=0.562 \times L_{\text {Rachis }}-0.767$ & Frond DW estimation using rachis length. \\
\hline 8 & Palm DW & $\begin{array}{l}D W_{\text {Palm }}=12.87+560.8 \times T_{\text {Vol }} \\
T_{\text {Vol }}=(\pi \times 0.5 \times D B H)^{2} \times L_{\text {Trunk }}\end{array}$ & $\begin{array}{l}\text { Palm DW estimation derived from non-destructive } \\
\text { trunk volume measurement. } \\
\text { DBH measured excluding frond bases. }\end{array}$ \\
\hline \multicolumn{4}{|c|}{ Derived Biomass Accumulation Models } \\
\hline $\mathrm{P} 1$ & Aboveground Biomass $\left(\mathrm{Mg} \mathrm{ha}^{-1}\right)$ & $A G B=6.389 \times Y A P-17.59$ & $\begin{array}{l}\text { AGB accumulation on peat - observed plantation } \\
\text { biomass. }\end{array}$ \\
\hline $\mathrm{P} 2$ & Aboveground Biomass $\left(\mathrm{Mg} \mathrm{ha}^{-1}\right)$ & $A G B=7.992 \times Y A P-26.29$ & $\begin{array}{l}\text { AGB accumulation on peat - 'perfect plantation' } \\
\text { model. All palms are modelled as live and standing. }\end{array}$ \\
\hline
\end{tabular}

Table 3. Allometric equations for the estimation of OP component dry weight (kg) and OP AGB accumulation models for $\mathrm{OP}$ on peat soils. Allometric equations are derived from destructive harvest data at the study site. Where $\mathrm{DW}_{\text {Frond }}$ is frond dry weight $(\mathrm{kg}), \mathrm{PCS}$ is the petiole cross sectional area $(\mathrm{cm}), \mathrm{DW}_{\text {Rachis }}$ is rachis dry weight $(\mathrm{kg}), \mathrm{DW}_{\text {Frag }}$ is rachis fragment dry weight $(\mathrm{kg}), \mathrm{L}_{\mathrm{Frag}}$ is rachis fragment length $(\mathrm{m}), \mathrm{L}_{\text {Rachis }}$ is rachis length $(\mathrm{m}), \mathrm{DW}_{\text {Trunk }}$ is trunk dry weight, $\mathrm{T}_{\text {Height }}$ is trunk height $(\mathrm{m}), \mathrm{DW}_{\text {Palm }}$ is palm dry weight $(\mathrm{kg}), \mathrm{T}_{\mathrm{Vol}}$ is trunk volume $\left(\mathrm{m}^{3}\right), \mathrm{DBH}$ is the diameter at breast height $(\mathrm{m})$ and YAP is years after planting.

components $^{12,30,37,38}$. This is likely due to the practical difficulties associated with frond base removal ${ }^{37}$. It is often also unclear whether non-destructive OP biomass assessments that quantify plantation biomass stocks using allometries have included the dry weight contribution of adhering frond bases ${ }^{8,9}$. Henson et al. (2012) found total frond base dry biomass per palm to be $10.8,62.8$ and $56.0 \mathrm{~kg}, 3,10$ and 13 years after planting in Papua New Guinea (with $94.6 \%$ of frond bases adhering to the trunk 13 YAP). Frond bases made an even greater contribution to overall palm biomass in this study, particularly in mature palms (Table 2). A review of studies quantifying frond base biomass highlights the high variation in palm frond base dry weight when compared to both palm age and trunk biomass ${ }^{37}$. Despite this variation, frond bases make a large contribution to the overall AGB of OP plantations in the young mature and mature age classes and will become a large carbon source following shedding before the end of the plantation planting cycle as frond base litter decomposes ${ }^{37,39}$.

The biomass of a single mature frond grown on peat was consistently lower than on mineral soils in all age classes when compared to pooled frond DWs for palms on mineral soils (Supplementary Fig. S4) ${ }^{40}$. Studies have also found the rate of frond emergence to reduce significantly as planting density is increased ${ }^{10,41}$. Taking into account the higher planting density of OP on peat, it is therefore surprising that there was no observable difference between total per palm frond biomass on mineral and peat soils (Fig. 3a). The acidity, low nutrient content and poor fertiliser retention of managed tropical peat soils is likely to result in reduced vegetative dry matter production and biomass accumulation when compared to OP on mineral soils ${ }^{42}$. In addition to this, palms at higher densities are subjected to increased competition for light thus reducing the dry matter production per palm ${ }^{23}$. Despite these expectations, our study revealed no notable differences in palm, trunk or frond biomass between mineral and peatland plantations. However, the lack of available literature which documents $\mathrm{DW}_{\text {Palm}}$, 

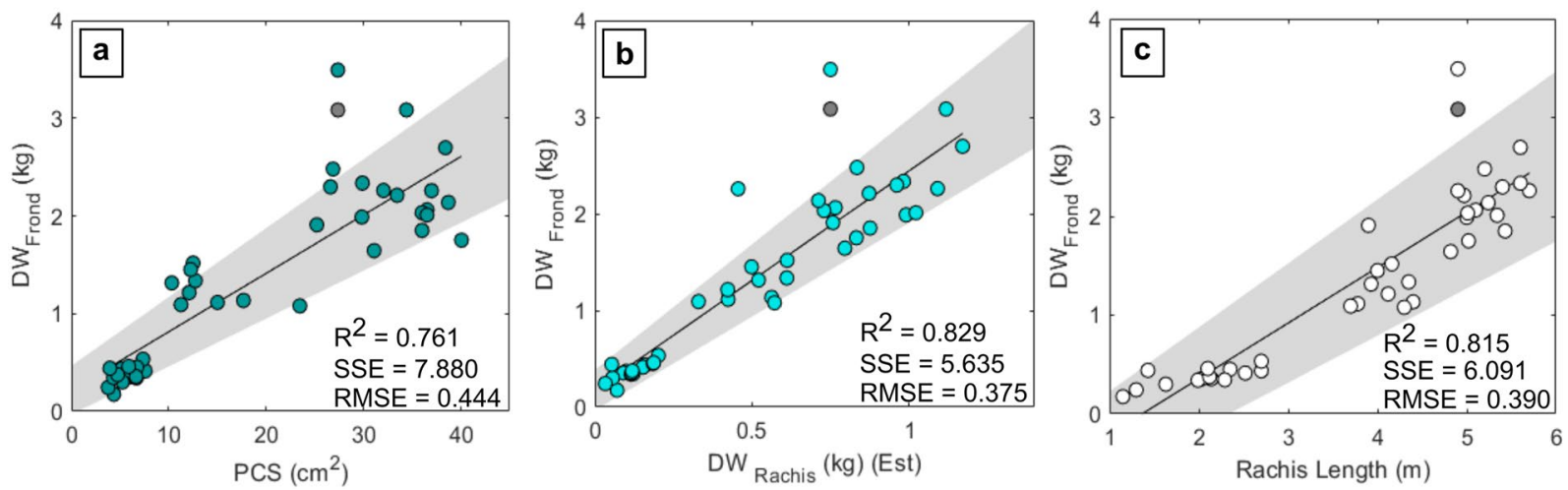

Figure 4. Linear relationship between frond structural characteristics and Frond DW (DW $\mathrm{Frond})$. $\mathrm{DW}_{\text {Frond }}$ is compared to the petiole cross sectional area (PCS) ((a) - equation (5)), rachis dry weight $\left(\mathrm{DW}_{\text {Rachis }}\right)$ derived from rachis linear density ((b) - equation (6)) and rachis length ((c) - equation (7)). A total of 45 fronds were sampled, fronds ranked 1, 9, 17, 25 and 33 were sampled for each of the nine destructively harvested palms. 95\% confidence interval of fit indicated in grey; consistent outliers indicated as a black closed circle.

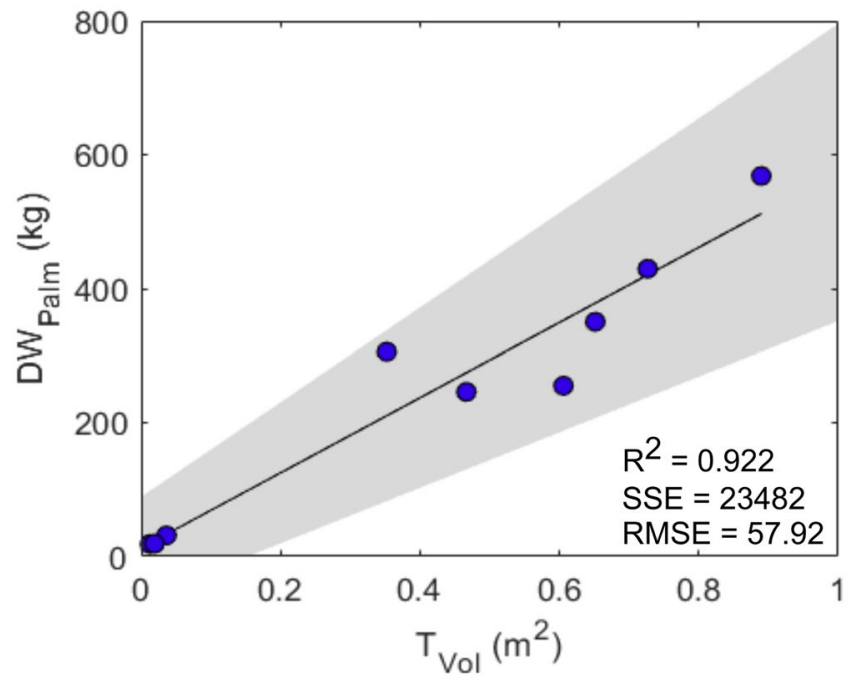

Figure 5. Linear relationship between palm trunk volume $\left(\mathrm{T}_{\mathrm{Vol}}\right)$ and palm dry weight $\left(\mathrm{DW}_{\mathrm{Palm}}\right)$ for the nine destructively sampled OPs. 95\% confidence interval of fit indicated in grey (Table 2, equation (8)).

$\mathrm{DW}_{\text {Trunk }}$ and the total frond biomass for individual palms on mineral soils and the small sample size of palms on peat in this study makes it difficult to identify significant differences in palm and component biomass. Difference may however be detectable with a larger sample size. To confound this, palms on mineral soils have been sampled using non-standardized methodologies and are influenced by differences in genotype, eco-region and plantation management ${ }^{8,11,12,26,30}$.

Allometric equations for OP component DW on peat. This study defined allometric relationships for $\mathrm{OP}$ and $\mathrm{OP}$ component dry biomass on drained tropical peats. Allometries produced here for the estimation of frond dry weight incorporate fronds of various ranks from multiple age classes. Here, the frond rachis linear density and petiole cross sectional area were both effective predictors of $D_{\text {Frond }}\left(R^{2}=0.82, R^{2}=0.76\right)$. In contrast to Corley and Tinker (1971) (Equation (1)), Aholoukpè et al. (2013) found frond biomass to be poorly predicted using the PCS in YM and M palms $\left(R^{2}=0.22\right)$ but found rachis linear density to be a better predictor $\left(R^{2}=0.62\right)$. However, the increased effort required to measure rachis linear density from the dry weight of a rachis fragment in the field is perhaps not justified by the marginally stronger relationship between rachis linear density and $\mathrm{DW}_{\text {Frond }}$ when compared to using the petiole cross sectional area in this study. An allometry was defined relating trunk volume to the total palm biomass (Equation (8)). To take into account the structural variation of OP on peat $\mathrm{T}_{\mathrm{Vol}}$ was modelled as a cylinder the length of the trunk to F33, measuring along the inner curve of the trunk for leaning palms ${ }^{32}$. 


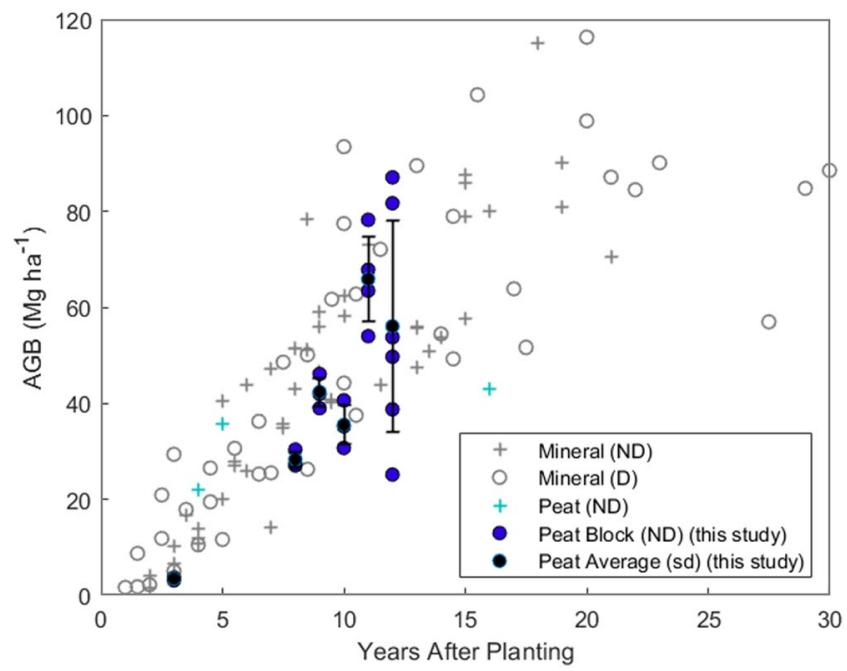

Figure 6. Oil palm block-level cumulative AGB stock $\left(\mathrm{Mg} \mathrm{ha}^{-1}\right)$ for peat (blue markers) and mineral soils (grey markers). OP aboveground biomass stocks on mineral soils (Table S1) were obtained using destructive (D) and non-destructive (ND) methods and are presented in addition to existing values for OP on peat. Existing data for non-destructive mineral estimates (grey+) and destructive mineral (open grey circle) and non-destructive peat $($ green +$)$. Block AGB stocks at the study site are included (closed blue circle) and the plantation mean for each YAP plotted (closed black circle), standard deviation indicated (Black error bars).
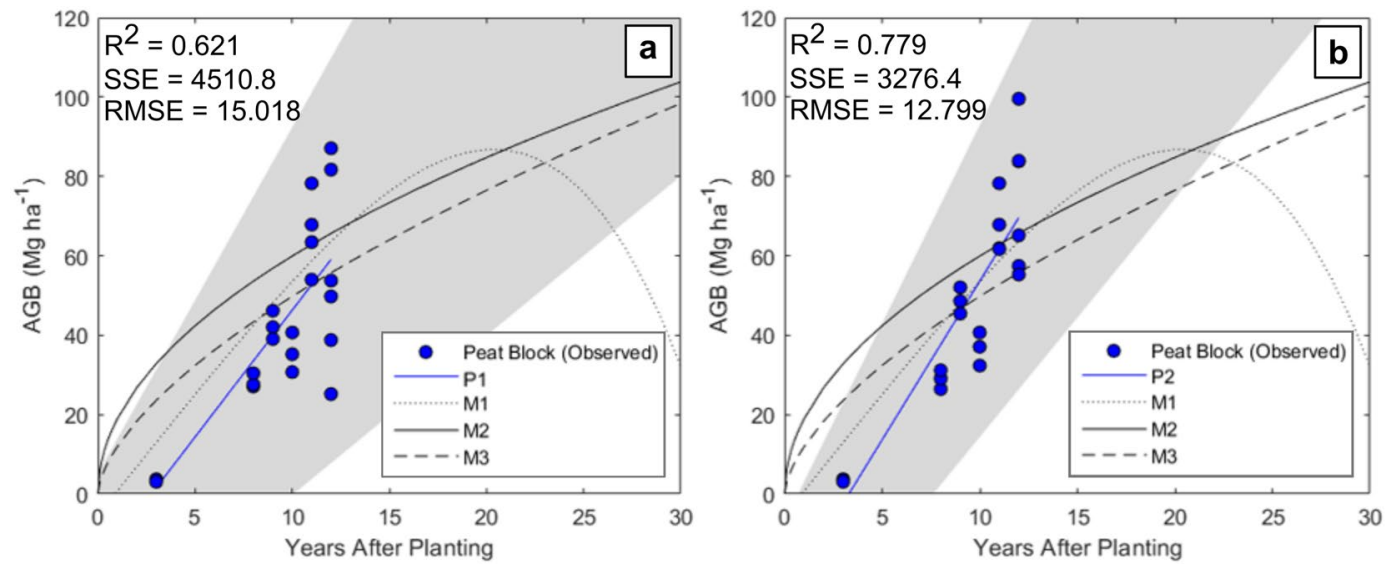

Figure 7. AGB accumulation models $\left(\mathrm{Mg} \mathrm{ha}^{-1}\right)$ for oil palm on deep peat from 3 to 12 YAP. (a) Models observed OP accumulation at the Sabaju and Sebungan OP estate complex (Model P1). (b) Models a 'perfect' plantation on peat modelling all palms as live, present and standing (Model P2). 95\% confidence intervals of both fits indicated in grey. Existing AGB accumulation models for OP on mineral soils (YAP 0-30) are plotted (Models 1, 2 and 3, Table 1).

Application of existing allometries to peat OP. Frond biomass for palms on peat was overestimated by the majority of existing allometric equations tested (derived using palms on mineral soils), most notably in the immature age class. This overestimation of young palm DW Frond is also acknowledged by Henson (1993) and a large improvement was observed when applying Equation (2), which is adjusted for use on young palm fronds. Equation (3) has yet to be validated for young palm fronds and whilst $\mathrm{DW}_{\text {rachis }}$ was well estimated for all age classes, adjustment is needed before it can be used for young palm $\mathrm{DW}_{\text {Frond }}$ prediction on peatlands ${ }^{43}$.

In the mature age classes, trunk biomass was underestimated by $\sim 32 \%$ when using Equation (4), much greater underestimation of $\sim 10 \%$ acknowledged by Morel et al. (2011) ${ }^{44}$ when using this allometry. Corley et al. (1971) model the trunk (without frond bases) as a cylinder with a constant diameter with wood density estimated according to palm age. Aholoukpè et al. $(2018)^{45}$ attempted reduce the uncertainty introduced though these assumptions by modelling the true inverted cone shape of the stem and incorporating the linear density of the trunk. However, this assumes an upright palm and hence is often not applicable to OP on peat due to high incidence of palm leaning 32 .

Here palm dry weight was best predicted using trunk volume. Thenkabail et al. (2004) relate $\mathrm{DW}_{\text {Palm }}$ to trunk height in Benin; the resulting allometry greatly underestimated $\mathrm{DW}_{\text {Palm }}$ in mature and young mature palms in 
this study resulting in a mean underestimation of $72 \%$. However, no palms with a trunk height $>1.95 \mathrm{~m}$ were incorporated into the initial model. Dewi et al. (2009) ${ }^{46}$ produced a similar allometry for OP on mineral soils in Indonesia which can be used more successfully with a mean underestimation of only $16 \%$ when applied here to OP on peat (Supplementary Table S3).

Plantation block-level AGB. The allometries developed using destructive sampling were combined with non-destructive palm structural measurements and frond pruning to upscale biomass stock estimates to the planation block level. Trunk DBH remained consistent across the age classes (YAP $>8$ ) whilst trunk length increased with age in standing palms (Supplementary Fig. S6). In 'successful' blocks, per hectare AGB was similar to that observed on mineral soils (Fig. 6). Vegetative dry matter production and standing biomass per hectare increases with planting density as observed in studies on both peat and mineral soils, disregarding fruit bunch biomass ${ }^{10,47}$. The higher planting density of palms on unfavourable peat soils likely contributes to the high per hectare AGB stocks in plots where leaning is infrequent or mild with relatively few fallen palms ${ }^{24,33}$. However, there is a large variation in plot per hectare AGB within age classes and in plots with a high incidence of leaning and fallen palms AGB was greatly reduced. Here, mild and severely leaning palms made up $17 \%$ of live palms in plots $>8$ YAP with an additional $13 \%$ of OPs fallen, missing or replaced. However, inter-plot variation within age classes across the plantation was high (Fig. 6). Census of the incidence of palm leaning were carried out at 6-month intervals in an experimental OP block on deep peat in Sarawak ${ }^{48}$. After 12 years $50.3 \%$ of palms were mildly leaning and $2.8 \%$ had fallen or were severely leaning, this worsened to 55.5 and $6.9 \%$ in uncompacted plots ${ }^{48}$. Dolmat et al. (1995) found leaning incidences of 44.2 (compacted) and $71.9 \%$ (uncompacted) in Perak.

As a result of the recent rise in OP expansion across tropical peats combined with efforts to increase peat OP sustainability, research increasingly focuses on the optimisation of peat OP growth and fruit bunch yields ${ }^{23,32,33}$. Prior to conversion, site and soil surveys are of high importance as the position on the peat dome, peat composition, maturity and depth have all been found to have an impact on conversion success, palm growth and yield potential $^{20,35}$. Peat compaction to increase bulk density prior to conversion and the thorough removal of woody debris from forest clearance is important to improve palm anchorage, whilst maintenance of a consistent water table increases palm rooting depth potential ${ }^{32,33,35,49,50}$. Once palms have reached maturity and leaning has commenced regular pruning to reduce canopy biomass and prevent toppling in addition to soil mounding roots after exposure both aid in reducing palm falling and limit AGB and yield reductions ${ }^{51}$.

Limitations and further work. In addition to the limitations highlighted, further uncertainties arise from the focus of this study on a single plantation. We observed a high variation in palm structural characteristics and plot biomass stocks within mature age classes in a single well managed industrial OP estate. Therefore, the actual variation of monoculture OP plantation AGB stocks on peat across Sarawak, Malaysia and Insular Southeast Asia is likely to be greater considering differences in plantation management and leaning, peat properties and ecoregions.

The sample size of destructively harvested palms is small $(n=9)$, with few mature palms and no palms $>12$ YAP harvested. Similar studies which destructively harvest palms on mineral soils to quantify $\mathrm{DW}_{\text {Palm }}$ include between 3 to 10 palms sampled for each palm age and span from 1.5 to 33 years after planting (Supplementary Table S3) ${ }^{11,12,26,30,52}$. Small sample sizes are common in destructive biomass assessments due to costly sampling procedures (particularly in older, larger palms) and results are therefore vulnerable to the influence of variation between individual palms $s^{9}$. We acknowledge the need to extend the temporal scope of the chronosequence here to include mature palms $>12$ YAP as AGB stocks after this point are uncertain. This could inform growth models for OP on peat beyond 18 YAP where existing models of OP AGB accumulation vary (Fig. 7) 3,21,28,53. Continuing the chronosequence would also permit the averaging of biomass stocks across the life of a plantation on peat, aiding in the comparison of biomass stocks with alternative land cover types for LUC flux modelling and carbon accounting ${ }^{6,54}$. Here all palm mortality and replacement has been attributed to palm leaning in the plots considered, however the spread of pests (particularly termites on peat soils) and diseases such as G. boninense basal stem or trunk rot are also frequently the cause of palm failure and replanting ${ }^{55,56}$. Despite this, the plantation studied here is in its first planting cycle and with no instances of $G$. boninense observed ${ }^{23}$.

Finally, all allometric relationships defined here would benefit from validation to test their success on OP on drained peats, including mature palms as well as their possible application in alternative ecoregions and at different planting densities ${ }^{17}$.

\section{Conclusion}

The recent rapid expansion of OP plantations across managed tropical peatlands is known to result in net carbon emissions. However, the emissions associated with this land use change across the life of a plantation remain poorly constrained as aboveground biomass accumulation rates on peat are uncertain due to a lack of both destructive and non-destructive AGB quantifications.

Here, we produce peat OP specific allometries for the estimation of both palm and frond dry weight and use these allometries to upscale AGB estimates to the plantation block level. This revealed a high variability in aboveground biomass stocks across a plantation in the mature age classes. Increasing non-destructive inventories on peat will not only improve AGB accumulation models but could also inform in-situ remote sensing efforts to quantify AGB stocks. Validating the allometries produced by expanding destructive harvests across different plantations on peat in addition to including older palms in harvests and plot inventories would further strengthen our understanding of peat OP AGB stock changes over time. 


\section{Methodology}

Study site. Measurements were carried out at the Sebungan and Sabaju Oil Palm Estate Complex, Sarawak, Malaysia $\left(3.19^{\circ} \mathrm{N} 113.43^{\circ} \mathrm{E}\right)$. The industrial OP plantation has an area of $\sim 10,200$ ha. The site receives $\sim 3075 \mathrm{~mm}$ rainfall per year with an average temperature of $27.2^{\circ} \mathrm{C}$. Meteorology was recorded at 1-minute intervals on a Sutron XLite 9210B datalogger (Sterling, Virginia, US). Air Temperature was measured at $1 \mathrm{~m}$ using a Vaisala HMP155 (Vaisala, Helsinki, Finland). Precipitation was measured at $6 \mathrm{~m}$, i.e. above the canopy, using a Texas Electronics TR525M (Dallas, Texas, US).

The plantation is low lying, soil surveys indicate a majority composition of lowland organic deposits with an underlying marine clay mineral layer $(84.8 \%)$. Very deep peat $(>3 \mathrm{~m}$ thick) covers the majority of the plantation; $42.2 \%$ has highly decomposed sapric surface $(0-0.5 \mathrm{~m})$ and subsurface $(0.5-1.5 \mathrm{~m})$ tiers. A further $42.6 \%$ is comprised of a partially decomposed sapric surface tier $(0-0.6 \mathrm{~m})$ and hemic subsurface tier $(0.5-1 \mathrm{~m})$. Both deposit types contain partially decomposed wood between $0.5-1 \mathrm{~m}$.

Prior to conversion the site was covered in logged mixed peat swamp forest (PSF). Land preparation included the removal of remaining large trees and vegetation, the establishment of a drainage system and peat compaction using heavy machinery ${ }^{31}$. OPs are planted at a density of 160 palms per hectare and at the time of measurement ranged from 3 to 12 years after planting (YAP).

Destructive harvests. Palm selection and sampling. Three palms were destructively harvested from each age class: 3 (Immature - I), 8 (Young Mature - YM) and 12 (Mature - M) years after planting. Palms were selected at random at least $50 \mathrm{~m}$ from the block edge, all were selected in different planting blocks, GPS coordinates were recorded (Supplementary Table S5). Severely leaning or recovered palms were not considered for destructive harvests. Prior to felling, non-destructive measurements of palm structural characteristics were taken.

Destructive measurements. All fresh weights (FW) $(\mathrm{kg})$ were measured and recorded at the felling site as close to the time of felling as possible, with particular attention paid to leaflets. Samples were promptly transferred to the lab oven to avoid capturing decomposition in DW measurements.

Fronds. Fronds were removed from the palm crown as close as possible to the base of the frond using a harvesting sickle (Fig. 1c). Fronds were counted and any petiole remaining in the crown subsequent to frond removal was harvested and classified as 'crown frond base'.

Using the frond rankings of Thomas et al., 1969, fronds 1, 9, 17, 25 and 33 were subsampled for allometric validation and development (Fig. 1ci). The petiole cross sectional area, rachis length and the fresh weights of the frond rachis, petiole and leaflets were recorded (Fig. 1c). Petiole cross sectional area was measured using callipers at the junction of rachis and petiole (the point of insertion of the lowest leaflet) and was modelled as a rectangle $(P C S=U \times V \text {, Fig. 1cii })^{11}$. A $0.15 \mathrm{~m}$ fragment was removed from the midpoint of the rachis and petiole, a subsample of leaflets was also removed. All remaining fronds were split into components (rachis, petiole and leaflets) and their total fresh weight recorded.

Trunk and frond bases. All epiphytes were removed from the palm trunk, the FW of epiphytes was recorded, and a subsample taken. All frond bases were removed from the palm trunk and a disk $\sim 0.2 \mathrm{~m}$ thick was removed from the trunk midpoint. This disk was weighed, and two perpendicular disk diameters recorded, a sector $\left(\sim 1 / 8^{\text {th }}\right.$ of the disk) was removed and the fresh weight recorded, and the sector returned to the labs for DW analysis. The palm trunk (without frond bases) was then weighed using suspended scales at the felling site or at the plantation weighbridge. Subsequent to removal, the total FW of all frond bases was recorded, a subsample of 3 frond bases was then returned to the labs.

Inflorescences, fruit, spear and cabbage. The total FW of all inflorescences and fruit bunches and the palm spear and cabbage (growing apex) was recorded at the felling site before removing 3 subsamples per component for DW analysis. Fruit bunch fresh and dry weights where not included in any further analysis due to variation in palm harvesting cycles.

Laboratory analysis. Palm component subsamples were dried at $105^{\circ} \mathrm{C}$ until a constant mass was reached, component moisture contents were then calculated for each sample.

Non-destructive surveys and frond pruning. Plot selection and sampling. Non-destructive survey plots were selected at random across the plantation complex (with a minimum of 3 plots selected for each age class). 22 plots with an area of 0.25 ha were surveyed. Plots were 3, 8, 9, 10, 11 and 12 YAP and were in independent planting blocks, GPS coordinates were recorded at plot corners. The YAP of each plot was checked against planting blocking maps, plots were established away from block edges (Supplementary Table S5).

Leaning categorisation. The condition of each palm with the 0.25 ha plot was recorded. Palms were categorised as upright, mildly leaning, severely leaning, recovered, fallen (dead/alive), missing or replanted (see Supplementary Table S4). The direction of lean was also recorded.

Non-destructive measurement and pruning. Each 0.25 ha plot contained approximately 40 palms, palms were numbered, and structural measurements taken for 10 randomly selected palms. The canopy height was recorded. Trunk length was measured along the trunk to frond 33 or the most mature frond, for leaning palms the trunk length was measured along the trunk inner curve (Fig. 1b, Supplementary Fig. S7). Trunk diameter at breast height $(\mathrm{DBH}, 1.3 \mathrm{~m})$ was measured using callipers so as not to include frond bases, for palms $<1.3 \mathrm{~m}$ in height the diameter was taken at the trunk midpoint. Frond 33 was pruned from the canopy of the corresponding palm; rachis length was recorded, and petiole cross sectional area was measured using callipers. 
Meta-analysis and allometry validation. OP biomass stock estimates. All accessible literature publishing per hectare standing biomass (SB) and AGB stocks for OP on both peat and mineral soils using destructive and non-destructive methods was collected. Values were adjusted to AGB $\left(\mathrm{Mg} \mathrm{ha}^{-1}\right)$, carbon contents were assumed to be $47.4 \%$ of dry biomass ${ }^{18}$. Where SB was reported AGB was assumed to be $84 \%$ of total SB based on assessments of belowground biomass (BGB) on mineral soils conducted by Corley and Tinker, 1971 and Khalid et al. ${ }^{12,13}$ (Root biomass $=16.1+/-5.3 \%$ of overall SB in palms $1.5-27.5$ YAP).

Allometric equations. Allometries for estimating palm component biomass derived using the destructive harvest of OP on mineral soils were collected and validated. Existing equations in the main section of the text (Table 1) are defined in peer reviewed literature, additional allometries are listed in the supplementary material.

Received: 25 October 2019; Accepted: 20 January 2020;

Published online: 10 February 2020

\section{References}

1. FAO. FAOSTAT http://www.fao.org/faostat/en/\#home (2019).

2. Miettinen, J., Shi, C., Liew, S. \& Land, C. cover distribution in the peatlands of Peninsular Malaysia, Sumatra and Borneo in 2015 with changes since 1990. Glob. Ecol. Conserv. 6, 67-78 (2016).

3. Hergoualc'h, K., Hendry, D. T., Murdiyarso, D. \& Verchot, L. V. Total and heterotrophic soil respiration in a swamp forest and oil palm plantations on peat in Central Kalimantan, Indonesia. Biogeochemistry. 135, 203-220 (2017).

4. Tonks, A. J. et al. Impacts of conversion of tropical peat swamp forest to oil palm plantation on peat organic chemistry, physical properties and carbon stocks. Geoderma. 289, 36-45 (2017).

5. Melling, L., Hatano, R. \& Goh, K. Soil CO2 flux from three ecosystems in tropical peatland of Sarawak, Malaysia. Tellus B 57, 1-11 (2005).

6. Murdiyarso, D., Hergoualc'h, K. \& Verchot, L. V. Opportunities for reducing greenhouse gas emissions in tropical peatlands. PNAS. 107, 1965-19660 (2010).

7. Page, S. E. et al. Review of peat surface greenhouse gas emissions from oil palm plantations in Southeast Asia. (The International Council on Clean Transport, 2011).

8. Germer, J. \& Sauerborn, J. Estimation of the impact of oil palm plantation establishment on greenhouse gas balance. Environ. Dev. Sustain. 10, 697-716 (2008).

9. Kho, L. K. \& Jepsen, M. R. Carbon stock of oil palm plantations and tropical forests in Malaysia: A review. SJTG 36, 249-266 (2015).

10. Henson, I. E. \& Dolmat, M. T. Physiological analysis of an oil palm density trial on a peat soil. J. Oil Palm. Res. 15, 1-27 (2003).

11. Corley, R. H. V., Gray, B. S. \& Ng, S. K. Productivity of the oil palm (Elaeis guineensis Jacq.) in Malaysia. Exp. Agric. 7, 129-136 (1971).

12. Khalid, H., Zin, Z. Z. \& Anderson, J. M. Quantification of oil palm biomass and nutrient value in a mature plantation. I. Aboveground biomass. J. Oil Palm. Res. 11, 23-32 (1999).

13. Khalid, H., Zin, Z. Z. \& Anderson, J. M. Quantification of oil palm biomass and nutrient value in a mature plantation. II. Belowground biomass. J. Oil Palm. Res. 11, 63-71 (1999).

14. Kumar, L. \& Mutanga, O. Remote sensing of above-ground biomass. Remote. Sens. 9, 935 (2017)

15. Mitchard, E. T. The tropical forest carbon cycle and climate change. Nat. 559, 527-534 (2018).

16. Gibbs, H. K., Brown, S., Niles, J. O. \& Foley, J. A. Monitoring and estimating tropical forest carbon stocks: making REDD a reality. Environ. Res. Lett. 2, 045023 (2007).

17. Picard, N., Saint-André, L. \& Henry, M. Manual for building tree volume and biomass allometric equations: from field measurement to prediction. (Food and Agricultural Organization of the United Nations, 2012).

18. Martin, A. R. \& Thomas, S. C. A reassessment of carbon content in tropical trees. PLoS ONE 6, 23533 (2011).

19. Chave, J. et al. Tree allometry and improved estimation of carbon stocks and balance in tropical forests. Oecologia 145, 87-99 (2005).

20. Melling, L., Goh, K. J., Uyo, L. J., Sayok, A. \& Hatano, O. Biophysical characteristics of tropical peatland. In: Proc. Conf. Peat and other soil factors in crop production (Ed. by Hamdan, J. et al.) Malaysian Society of Soil Science, Serdang, Selangor 110-119, (2007).

21. Carlson, K. M. et al. Committed carbon emissions, deforestation, and community land conversion from oil palm plantation expansion in West Kalimantan, Indonesia. PNAS 109, 7559-7564 (2012).

22. Carlson, K. M. et al. Carbon emissions from forest conversion by Kalimantan oil palm plantations. Nat. Clim. Change. 3, 283 (2013).

23. Corley, R. H. V. \& Tinker, P. B. The oil palm. (John Wiley \& Sons, 2016).

24. Woittiez, L. S., van Wijk, M. T., Slingerland, M., van Noordwijk, M. \& Giller, K. E. 2017. Yield gaps in oil palm: A quantitative review of contributing factors. Eur. J. Agron. 83, 57-77 (2017).

25. Corley, R. H. V. \& Gray, B. S. Yield and yield components in Oil palm research (eds. Corley, R. H. V., Hardon, J. J. \& Wood, B. J.), pp. 77-86, (Elsevier, 1976).

26. Rees, A. R. \& Tinker, P. B. H. Dry-matter production and nutrient content of plantation oil palms in Nigeria. Plant. Soil. 19, 19-32 (1963).

27. Thomas, R. L., Chan, K. W. \& Easau, P. T. Phyllotaxis in the oil palm: arrangement of fronds on the trunk of mature palms. Ann. Bot. 33, 1001-1008 (1969).

28. Henson, I. E. The Malaysian national average oil palm: concept and evaluation. Oil Palm. B 46, 15-27 (2003).

29. Henson, I. E. OPRODSIM, a versatile, mechanistic simulation model of oil palm dry matter production and yield. In: Proc. Conf. PIPOC 2005 International Palm Oil Congress, Agriculture, Biotechnology and Sustainability Conference (801-832). Malaysian Palm Oil Board Kuala Lumpur (2005).

30. Syahrinudin, S. The potential of oil palm and forest plantations for carbon sequestration on degraded land in Indonesia. (ed. Vlek, P. L .G., Denich, M., Martius, C., Rodgers, C. \& Giese, N. V. D.) (Ecology and Development Series, Cuvillier Verlag, Göttingen, 2005).

31. Cook, S. et al. 2018. Fluvial organic carbon fluxes from oil palm plantations on tropical peatland. Biogeosciences 15, 7435-7450 (2018).

32. Lim, K. H., Lim, S. S, Parish. F. \& Suharto, R. RSPO Manual on Best Management Practices (BMPs) for Existing Oil Palm Cultivation on Peat. (Roundtable on Sustainable Palm Oil, 2012).

33. Othman, H., Mohammed, A. T., Harun, M. H., Darus, F. M. \& Mos, H. Best management practises for oil palm planting on peat: optimum groundwater table. MPOB Inf. Ser. 528, 1-7 (2010).

34. Melling, L. \& Henson, I. E. Greenhouse gas exchange of tropical peatlands-a review. J. Oil Palm. Res. 23, 1087-1095 (2011).

35. Veloo, R., Van Ranst, E. \& Selliah, P. 2015. Peat characteristics and its impact on oil palm yield. NJAS. 72, 33-40 (2015).

36. Hooijer, A. et al. Current and future CO2 emissions from drained peatlands in Southeast Asia. Biogeosciences. 7, 1505-1514 (2010).

37. Henson, I. E., Betitis, T., Tomda, Y. \& Chase, L. D. The estimation of frond base biomass (FBB) of oil palm. J. Oil Palm. Res. 24, 1473-1479 (2012). 
38. Caliman, J. P., Carcasses, R., Girardin, P., Pujianto, D. B. \& Liwang, T. 'Development of agrienvironmental indicators for sustainable management of oil palm growing: general concept and the example of nitrogen.' PIPOC 2005 International Palm Oil Congress: Agriculture, Biotechnology and Sustainability. Kuala Lumpur, Malaysia (2005).

39. Khalid, H., Zin, Z. Z. \& Anderson, J. M. Decomposition processes and nutrient release patterns of oil palm residues. J. Oil Palm. Res. $12,46-63(2000)$.

40. Henson, I. E. Modelling vegetative dry matter production of oil palm. Oil Palm. Bull. 52, 25-47 (2006).

41. Kwan, B. K. W. The effect of planting density on the first fifteen years of growth and yield of oil palm in Sabah (Sabah Department of Agriculture, 1994).

42. Dolmat, M., Hamdan, A. B., Zulkifli, H. \& Ahmad Tarmizi, M. Fertiliser requirement of oil palm on peat - an update. In: Proc. Conf.1996 PORIM International Palm Oil Congress: Competitiveness for the 21st century (eds. Ariffin et al.), Palm Oil Research Institute of Malaysia, Kuala Lumpur, 131-142 (1996)

43. Aholoukpé, H. N. S. et al. Estimating aboveground biomass of oil palm: allometric equations for estimating frond biomass. Forest. Ecol. Manag. 292, 122-129 (2013).

44. Morel, A. C. et al. Estimating aboveground biomass in forest and oil palm plantation in Sabah, Malaysian Borneo using ALOS PALSAR data. For. Ecol. Manag. 262, 1786-1798 (2011).

45. Aholoukpè, H. N. S. et al. Allometric equations for estimating oil palm stem biomass in the ecological context of Benin, West Africa. Trees 32, 1669-1680 (2018).

46. Dewi, S., Khasanah, N., Rahayu, S., Ekadinata A. \& van Noordwijk, M. Carbon Footprint of Indonesian Palm Oil Production: a Pilot Study. (World Agroforestry Centre, 2009).

47. Corley, R. H. V. Effects of plant density on growth and yield of oil palm. Exp. Agric. 9, 169-180 (1973).

48. Hasnol, O., Darus, F. M. \& Mohammed, A. T. Experiences in Peat Devalopment of Oil Palm Planting in the MPOB Research Station at Sessang, Sarawak. Oil Palm. Bulletin. 58, 1-13 (2009).

49. Dolmat, M., Hamdan, A. B. \& Zulkifli, H. Novel agronomic innovations in the exploitation of peat for oil palm. In: Proc. 1993 PORIM International Palm Oil Congress: Agriculture (Ed. by Jalani, B. S. et al.), Palm Oil Research Institute of Malaysia, Kuala Lumpur, 360-372 (1995).

50. Tie, Y. L. Long-term drainability of and water management in peat soil areas. Planter. 80, 423-439 (2004).

51. Lim, K. H. \& Herry, W. 'Management of leaning and fallen palms planted on tropical peat.' IOPRI International Oil Palm Conference 2010. Yogyakarta, Indonesia (2010).

52. Thenkabail, P. S. et al. Biomass estimations and carbon stock calculations in the oil palm plantations of African derived savannas using IKONOS data. Int. J. Remote. Sens. 25, 1-27 (2004).

53. Henson, I. E. A Review of Models for Assessing Carbon Stocks and Carbon Sequestration in Oil Palm Plantations. J. Oil Palm. Res. 29, 1-10 (2017).

54. Agus, F. et al. Review of emission factors for assessment of $\mathrm{CO} 2$ emission from land use change to oil palm in Southeast Asia. (Roundtable for Sustainable Palm Oil (RSPO), 2013).

55. Cheng, S., Kirton, L. G. \& Gurmit, S. Termite attack on oil palm grown on peat soil: identification of pest species and factors contributing to the problem. Plant. 84, 659-670 (2008).

56. Ariffin, D., Gurmit, S. \& Lim, T. K. 'Ganoderma in Malaysia - current status and research strategy' 1989 International Palm Oil Development Conference, (eds. Jalani, B. S. et al.) Kuala Lumpur, Malaysia (1990).

\section{Acknowledgements}

The authors would like to thank the Director-General of the Malaysian Palm Oil Board for permission to publish these results. This study was carried out as part of a wider tropical peat research collaboration between MPOB, University of Exeter and University of Aberdeen and we would like to thank the MPOB staff and the Sarawak Oil Palm Berhard for help and support during the project. Specifically, from the Sarawak Oil Palm Berhard we would like to thank: Mr. Paul (group CEO), Mr. Chua Kian Hong (group plantation manager), Mr. Phang Seng Nam (regional plantation controller) and Mr. Sammy (Sabaju plantation manager) for being kind enough to allow this research to be carried out within their plantation and for the provision of logistical support. From MPOB we would like to thank the dedicated field technicians, Steward Saging and Ham Jonathon for their invaluable support.

\section{Author contributions}

K.L. wrote the paper with contributions from E.R., L.K.K., J.M., Y.A.T., A.G.S. and T.C.H. The experimental design for this project was led by K.L. with input from all authors. The fieldwork was led by K.L. and E.R. with support in field from J.M. and L.K.K. The data processing and analysis was led by K.L. with input from T.C.H., and contributions from all authors. This study forms part of a project which was conceived jointly by L.K.K., T.C.H. and Y.A.T.

\section{Competing interests}

The research was carried out as part of a project funded by the Malaysian Palm Oil Board (MPOB). MPOB is a government agency responsible for the promotion and development of the palm oil industry. J.M. is the project PDRA based at the University of Exeter and the project is led by T.C.H., Y.A.T. and L.K.K. Both L.K.K. and E.R. are employees of MPOB. The research was carried out with the support of Sarawak Oil Palm Berhard (SOPB) on whose land the research project was based. K.L. and A.G.S. declare no competing interests and are associated solely with the University of Exeter.

\section{Additional information}

Supplementary information is available for this paper at https://doi.org/10.1038/s41598-020-58982-9.

Correspondence and requests for materials should be addressed to K.L.

Reprints and permissions information is available at www.nature.com/reprints.

Publisher's note Springer Nature remains neutral with regard to jurisdictional claims in published maps and institutional affiliations. 
cc) (i) Open Access This article is licensed under a Creative Commons Attribution 4.0 International License, which permits use, sharing, adaptation, distribution and reproduction in any medium or format, as long as you give appropriate credit to the original author(s) and the source, provide a link to the Creative Commons license, and indicate if changes were made. The images or other third party material in this article are included in the article's Creative Commons license, unless indicated otherwise in a credit line to the material. If material is not included in the article's Creative Commons license and your intended use is not permitted by statutory regulation or exceeds the permitted use, you will need to obtain permission directly from the copyright holder. To view a copy of this license, visit http://creativecommons.org/licenses/by/4.0/.

(c) The Author(s) 2020 